\title{
Analisis Tutupan Lahan Menggunakan Metode Klasifikasi Tidak Terbimbing Citra Landsat di Sawahlunto, Sumatera Barat
}

\author{
Land Cover Analysis using Unsupervised Classification Method of Landsat Imagery in Sawahlunto, West Sumatera
}

\author{
Bowo Eko Cahyono*, Ervin Budi Febriawan, Agung Tjahjo Nugroho
}

\author{
Jurusan Fisika. FMIPA. Universitas Jember JI. Kalimantan 37, Jember 68121 \\ *E-mail: bowo_ec.fmipa@unej.ac.id
}

Diterima: 28 November 2018; Disetujui: 20 April 2019

\begin{abstract}
ABSTRAK
Penginderaan jauh merupakan pengkajian atas informasi mengenai daratan dan permukaan air bumi dengan menggunakan citra yang diperoleh dari sudut pandang atas (overhead perspective), menggunakan radiasi elektromagnetik dalam satu beberapa bagian dari spektrum elektromagnetik yang dipantulkan atau dipancarkan dari permukaan bumi. Teknologi ini digunakan untuk menganalisis tutupan lahan melalui analisis citra hasil perekaman satelit penginderaan jauh Landsat di Kota Sawahlunto, Provinsi Sumatera Barat, Indonesia (040'16" LU dan 100 47'21" BT) yang diduga mengalami perubahan karena adanya aktivitas pertambangan batu bara. Metode klasifikasi tutupan lahan yang digunakan adalah metode klasifikasi tidak terbimbing pada band RGB (Red, Green, and Blue). Hasil penelitian mengindikasikan adanya perubahan lahan berupa perubahan luas hutan pada periode tahun 2000 - 2006, 2006 - 2011, dan 2011 - 2016 masing-masing sebesar $1,19 \mathrm{~km}^{2}, 19,72 \mathrm{~km}^{2}$, dan $7,27 \mathrm{~km}^{2}$. Nilai matrik konfusi menunjukkan overall accuracy tertinggi terdapat pada tahun 2000 sebesar $100 \%$ dan terendah pada tahun 2016 sebesar 92,5\%. Akurasi yang beragam ini terjadi karena ada pengaruh dari tingkat cloud cover citra yang digunakan. Cloud cover pada tahun 2000 sebesar 9,0\% dan cloud cover pada tahun 2016 sebesar $14,3 \%$. Semakin tinggi cloud cover data yang digunakan maka akan semakin rendah overall accurary yang didapat dan semakin rendah cloud cover data yang digunakan maka akan semakin tinggi overall accurary yang didapat. Hasil penelitian juga menunjukkan bahwa aktifitas pembukaan lahan hutan menjadi tambang, pemukiman, dan danau/air pada periode tahun 2000 - 2011 berpengaruh negatif pada kualitas dari kehijauan hutan. Sebaliknya, dengan berkurangnya aktifitas pembukaan lahan menjadi pemukiman, tambang, dan danau/air akan berdampak positif pada kualitas hutan.
\end{abstract}

Kata kunci: band; klasifikasi tidak terbimbing; overall accurary; pembukaan lahan; pengindraan jauh

\section{ABSTRACT}

Remote sensing is an assessment of information on terrestrial and surface water using images obtained from an overhead perspective, using electromagnetic radiation in a few parts of the electromagnetic spectrum reflected or emitted from the earth's surface. This technology was used to analyze land cover through recorded imagery of Landsat remote sensing satellite in Sawahlunto, West Sumatra Province, Indonesia (0 $0^{\circ} 40^{\prime} 16^{\prime \prime}$ latitude and $100^{\circ} 47^{\prime} 21^{\prime \prime}$ longitude) which experienced change due to mining activities (coal). The land cover classification method used was unsupervised classification method in the RGB (Red, Green, and Blue) bands. The results of this study showed that there were significant change in land cover especially in forest area over the period 2000 - 2006, 2006 - 2011, and 2011 - 2016 around $1.19 \mathrm{~km}^{2}, 19.72 \mathrm{~km}^{2}$, and 7.27 $\mathrm{km}^{2}$, respectively. Its confusion matrix value showed the highest overall accuracy in 2000 at $100 \%$ and the lowest in 2016 at 92.5\%. This diverse accuracy occurs because there was an influence from the level of cloud cover from used image. Cloud cover in 2000 was nearly 9.0\% and in 2016 about 14.3\%. The higher the cloud cover data used, the lower the overall accurary obtained and the lower the cloud cover data used, the higher the overall accurary obtained. The results of the study also showed that the activities of land convertion from forest into mining area, settlements, and lakes/water over the period 2000 - 2011 gave negative impact to the the forest quality. In contras, the reduction of land clearing activities gave a positive impact to the forest quality.

Keywords: band, land clearing; overall accurary; remote sensing; unsupervised classification

\section{PENDAHULUAN}

Menurut Ilandayani dan Setiyadi (2003) penginderaan jauh merupakan pengkajian atas informasi mengenai daratan dan permukaan air bumi dengan menggunakan citra yang diperoleh dari sudut pandang atas (overhead perspective), menggunakan radiasi elektromagnetik dalam satu beberapa bagian dari spektrum elektromagnetik yang dipantulkan atau dipancarkan dari permukaan bumi. Dengan demikian dapat diartikan, pengindraan jauh sebagai salah satu aplikasi untuk mempelajari informasi permukaan bumi.
Penggunaan teknologi penginderaan jauh untuk mendeteksi perubahan obyek terdiri dari 10 aspek (Sutanto, 1994) yakni: (1) tutupan dan penggunaan lahan, (2) perubahan hutan atau vegetasi, (3) penilaian kerusakan hutan dan defoliasi, (4) deforestasi, regenerasi dan permanen selektif, (5) perubahan lahan basah atau wetland, (6) kebakaran hutan, (7) perubahan lanskap, (8) perubahan daerah Kota, (9) perubahan lingkungan, (10) perubahan lainnya seperti monitoring tanaman, monitoring perladangan perpindah dan segmentasi jalan. Selanjutnya, masing-masing aspek tersebut akan saling mempengaruhi terhadap aspek lainnya. 
Tutupan lahan adalah kenampakan material fisik di permukaan bumi dimana tutupan lahan menggambarkan keterkaitan antara proses alami dan proses sosial. Tutupan lahan juga dapat menyediakan informasi yang penting bagi keperluan pemodelan dan untuk memahami fenomena alam yang terjadi di permukaan bumi. Data tutupan lahan juga digunakan dalam mempelajari perubahan iklim dan memahami keterkaitan antara aktivitas manusia dan perubahan global. Informasi tutupan lahan yang akurat merupakan salah satu faktor penentu dalam meningkatkan kinerja dari model-model ekosistem, hidrologi, dan atmosfer. Selain itu, tutupan lahan juga menyediakan informasi dasar dalam kajian geoscience dan perubahan global (Sampurno dan Thoriq, 2016).

Perubahan tutupan lahan juga terjadi pada kawasan pertambangan Kota Sawahlunto Provinsi Sumatera Barat. Hal ini disebabkan karena adanya kegiatan pertambangan yakni tambang batu bara, telah mengubah kondisi tutupan lahan daerah tersebut (Frahma et. al., 2018). Secara otomatis perubahan ini berdampak pada perubahan vegetasi yang ada disekitar kawasan tersebut. Berdasarkan alasan tersebut, Kota Sawahlunto dipilih dalam penelitian ini untuk melihat perubahan tutupan yang terjadi. Fakta menunjukkan bahwa pada tahun 2010 terdapat sekitar 10 perusahaan tambang batu bara yang beroperasi di Kota Sawahlunto. Hal ini menunjukkan bahwa lahan Kota Sawahlunto telah beralih fungsi menjadi suatu daerah pertambangan. Semakin luas lokasi yang digunakan untuk pertambangan juga berdampak terhadap semakin sempit lahan hutan dan secara otomatis akan mempengaruhi berkurangnya tingkat kerapatan vegetasi yang ada di Kota Sawahlunto. Apabila hal ini terus menerus dibiarkan maka akan berdampak pada lingkungan di Kota Sawahlunto itu sendiri. Kota Sawahlunto merupakan kabupaten yang terletak di daerah dataran tinggi yang merupakan bagian dari Bukit Barisan. Kota Sawahlunto memiliki luas 273,92 $\mathrm{km}^{2}$ dan lebih dari 26,5 persen dari luas Kota Sawahlunto merupakan kawasan perbukitan yang ditutupi hutan lindung. Penggunaan lahan yang dominan di Kota ini adalah perkebunan sekitar 34 persen dan danau yang terbentuk dari bekas galian tambang batu bara sekitar 0,2 persen (Unesco, 2017).

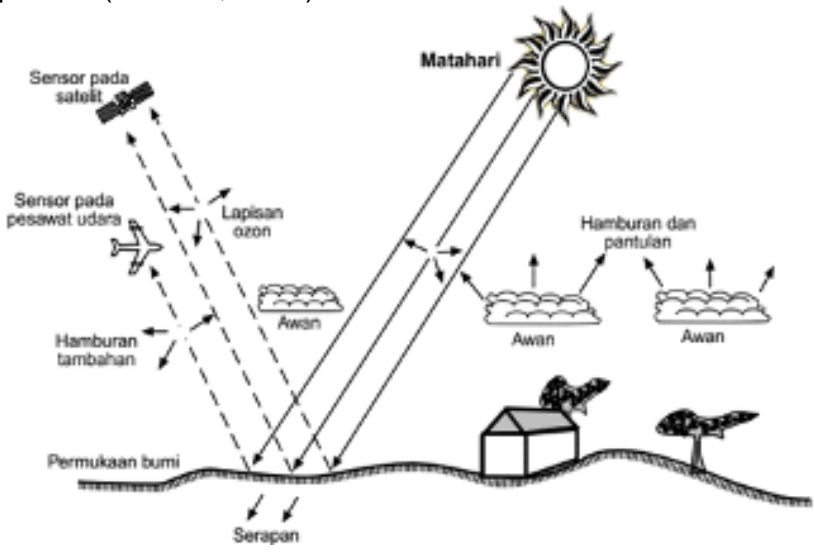

Gambar 1.Interaksi antara Gelombang Elektromagnetik dengan Atmosfer (Wahyuni, 2015)

Monitoring tutupan lahan dan perubahannya saat ini dapat dilakukan secara lebih mudah dan cepat dengan menggunakan teknologi remote sensing (Alba et. al., 2012). Teknologi tersebut bekerja berdasarkan identifikasi karakteristik spectral dari object yang ada di permukaan bumi (Sabins, 1987; Levin, 1999; Campbell, 2002). Sumber data yang digunakan dapat berupa citra fotografi (Cahyono et. al., 2018) maupun citra dari satelit (Compton et. al., 1985). Instrument yang digunakan untuk pengambilan citra mendeteksi gelombang elektromagnetik yang dipantulkan oleh objek (Rees, 2001). Dalam penjalarannya ke permukaan bumi, gelombang elektromagnetik tersebut berinteraksi dengan atmosfer seperti yang diilustrasikan pada Gambar 1.

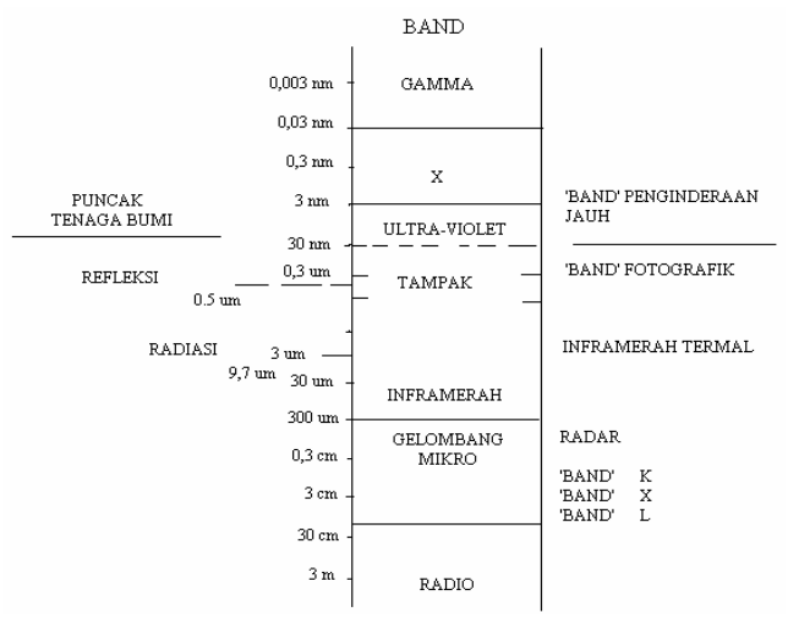

Gambar 2. Gelombang Elektromagnetik (Arnanto, 2013)

Sebagian spektrum elektromagnetik yang dapat mencapai permukaan bumi diserap oleh obyek di permukaan bumi, sedangkan sisanya dipantulkan olehnya hingga mencapai sensor yang dipasang pada pesawat terbang, satelit atau wahana lainnya. Setiap obyek mempunyai karakteristik tersendiri di dalam menyerap dan memantulkan gelombang yang diterima olehnya. Karakteristik ini disebut dengan karakteristik spektral (Wahyuni, 2015).

\section{METODE}

Jenis data yang digunakan adalah data kuantitatif. Data kuantitatif merupakan suatu data informasi yang berupa simbol angka atau bilangan. Berdasarkan simbol-simbol angka tersebut, perhitungan secara kuantitatif dapat dilakukan untuk menghasilkan suatu kesimpulan yang berlaku umum di dalam suatu parameter. Data kuantitatif ini adalah berupa nilai indeks vegetasi yang didapatkan dari proses pengolahan data citra satelit Landsat dan luasan pada setiap kelas klasifikasi. Data yang digunakan adalah data sekunder berupa citra satelit Landsat 5 dan Landsat 8 .

Variabel yang digunakan ada 2 macam, yakni variabel terikat dan variabel bebas. Variabel terikat pada adalah nilai indeks vegetasi dan perubahan tutupan lahan serta konversinya. Perubahan tutupan lahan dapat diidentifikasi dengan melakukan klasifikasi terhadap tutupan lahan tersebut. Kelas klasifikasi tutupan lahan terdiri dari empat yakni hutan, tambang, danau/air serta pemukiman. Sedangkan variabel bebas berupa data citra satelit Landsat.

Gambar 3 mengilustrasikan langkah kerja yang dilakukan dalam penelitian ini. Tahap persiapan adalah tahapan yang meliputi perolehan dan pengkoreksian data citra satelit yang digunakan dalam penelitian.

\section{Pengambilan Data Citra Landsat}

Citra Landsat yang digunakan adalah path 112 dan row 062 yang melingkupi Kota Sawahlunto Provinsi Sumatera Barat, Indonesia. Path dan row menunjukkan kode wilayah pada citra. Row merupakan baris yang menunjukkan keberadaan suatu wilayah dari utara ke selatan sedangkan 
path merupakan baris yang menunjukkan keberadaan suatu wilayah dari barat ke timur. Pemilihan data citra Landsat pada penelitian ini dikarenakan data citra Landsat memiliki resolusi spasial yang baik yakni 30 meter dan resolusi temporal 16 hari sehingga dianggap mencukupi untuk digunakan dalam perubahan lahan di Kota Sawahlunto ini. Citra Landsat pada penelitian ini diperoleh dari United States Geological Survey (USGS).

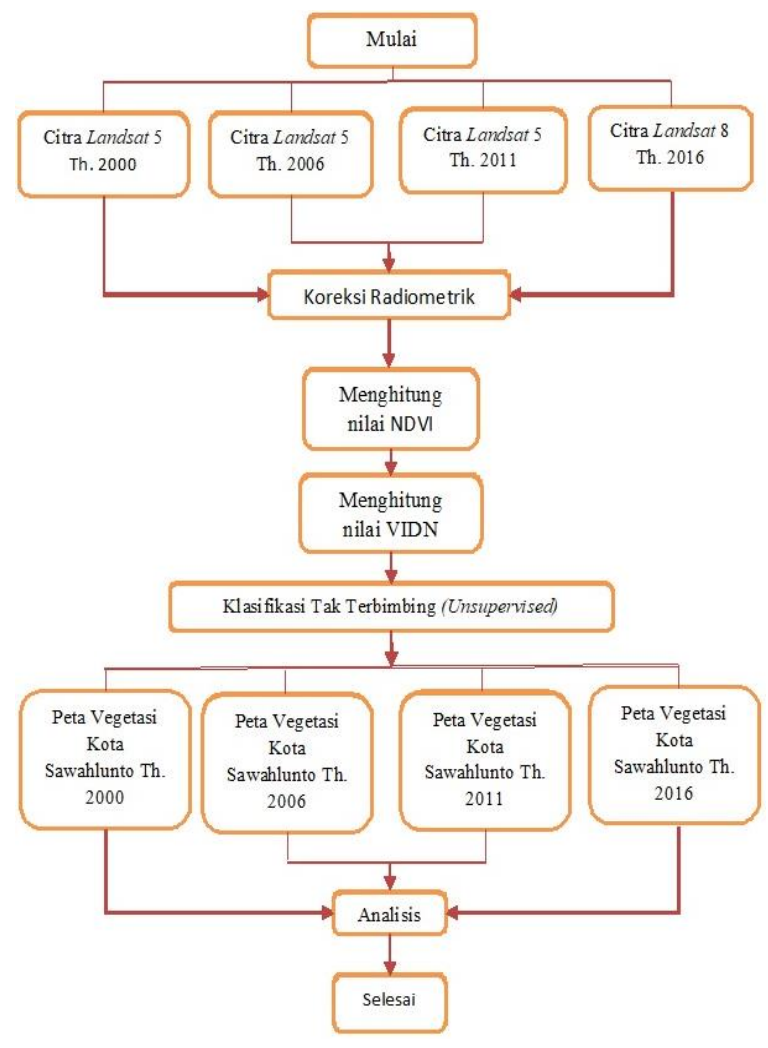

Gambar 3. Diagram Kerja Penelitian

\section{Pengkoreksian Data Citra Landsat}

Koreksi radiometrik dilakukan bertujuan untuk mengubah nilai digital number setiap piksel-piksel citra menjadi nilai reflektansi yang mewakili objek di permukaan bumi yang terekam pada citra Landsat. Koreksi radiometrik menghilangkan pengaruh dinamika atmosfer yang terjadi. Koreksi radiometrik sering disebut juga dengan nama koreksi Top of Atmosfer (ToA). Proses koreksi radiometrik dilakukan dengan menggunakan software Quantum GIS (QGIS). Citra terkoreksi disimpan dalam dalam format "tiff".

Tahap pengolahan pada citra Landsat ini terdiri dari tiga bagian yaiyu perhitungan nilai indeks vegetasi NDVI, VIDN dan klasifikasi.

\section{Normalized Diffrence Vegetation Index (NDVI)}

Perhitungan indeks vegetasi dimulai dengan menerapkan persamaan NDVI pada masing-masing citra. Untuk memperoleh nilai NDVI maka harus disediakan data citra Landsat. Setiap data citra satelit Landsat tersebut diambil band NIR dan Red. Pada Landsat 5 dan 7 band NIR terletak di band nomor 4 dan Red terletak di band nomor 3 . Sedangkan pada Landsat 8 band NIR terletak di nomor 5 dan Red terletak di band nomor 4. Nilai NDVI suatu data citra satelit Landsat diolah dengan menggunakan software QGIS (Quantum GIS). Hasil dari NDVI data citra landsat berupa data citra berformat "tiff".

\section{Vegetation Index Differencing (VIDN)}

Setelah masing-masing data citra Landsat tersebut diperoleh nilai NDVI maka tahap selanjutnya adalah mencari nilai VIDN. Nilai VIDN merupakan nilai yang diperoleh dari pengurangan nilai NDVI dua waktu yang berbeda. Nilai VIDN digunakan untuk analisis perubahan diperoleh dari pengurangan nilai NDVI dua citra yang berbeda tahun.

\section{Klasifikasi dan Analisa}

Metode klasifikasi yang digunakan adalah metode klasifikasi tak terbimbing (unsupervised classification) yang merupakan salah satu metode untuk interpretasi citra. Hasil dari klasifikasi ini berupa citra yang terdiri dari 4 kelas dan berformat "tiff".

Tahap analisa dimulai dengan mengidentifikasi data citra dari hasil NDVI, VIDN, dan Klasifikasi. Data citra tersebut dirubah dalam bentuk angka. Hasil NDVI ditampilkan dalam bentuk tabel dengan kolom kisaran, ratarata, dan rataan dari masing-masing kelas (hutan, pemukiman, tambang, dan danau atau air). Dari tabel tersebut, ditampilkan grafik perubahan nilai NDVI setiap tahunnya. Hasil VIDN ditampilkan dalam bentuk tabel dengan membandingkan nilai VIDN dari tahun 2000 dengan 2006, 2006 dengan 2011, dan 2011 dengan 2016. Nilai VIDN yang dibandingkan akan melihat perubahan objek dari hutan menjadi pemukiman, hutan menjadi tambang, hutan menjadi air, pemukiman menjadi tambang, pemukiman menjadi air, dan tambang menjadi air.

Hasil klasifikasi tak terbimbing selanjutnya ditampilkan dalam peta tutupan lahan setiap tahunnya. Peta tutupan lahan tersebut berisi informasi pembagian kelas pada klasifikasi mulai dari hutan, pemukiman, tambang dan danau atau air. Selain peta tutupan lahan, juga disertakan tabel luas setiap kelas tutupan lahan yang dibuat berdasarkan klasifikasi tutupan lahan setiap tahunnya. Keakuratan hasil klasifikasi tak terbimbing diuji berdasarkan pengujian akurasi overall accuracy. Pengujian akurasi disajikan dalam bentuk tabel matrik konfusi yang berisi user accurary, produser accurary, dan overall accurary. Dari hari pengujian akurasi tersebut, diketahui seberapa akurat metode klasifikasi tak terbimbing yang diapkilasikan pada tutupan lahan.

\section{HASIL DAN PEMBAHASAN}

\section{Koreksi Citra}

Koreksi Radiometrik (ToA) dilakukan pada menu Semi Automatic Classification yang terdapat pada software QGIS. Didalam menu Semi Automatic Classification terdapat tab Landsat yang dapat mengkonversi data Landsat 4, 5, 7, dan 8 dari nilai Digital Number (DN) menjadi nilai reflektansi. Setelah semua isian pada tab Landsat selesai dipilih dan diisi, maka selanjutnya dipilih Perform Conversion untuk menjalankan proses koreksi radiometrik pada citra Landsat. Setelah proses tersebut selesai maka didapatkan hasil citra Landsat yang telah terkoreksi Radiometrik. Berikut ini adalah contoh citra landsat sebelum dan sesudah dikoreksi secara radiometrik. Selanjutnya akan terlihat bahwa fitur-fitur pada citra yang sudah dilakukan koreksi radiometrik menjadi tampak lebih jelas (Gambar 4). 


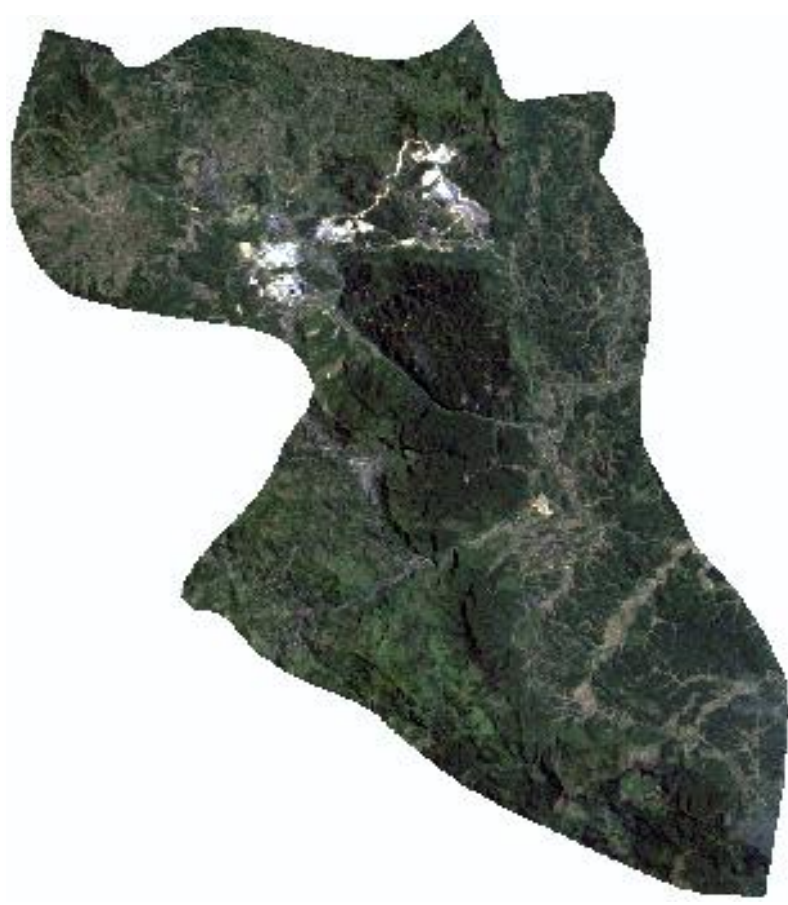

(a)

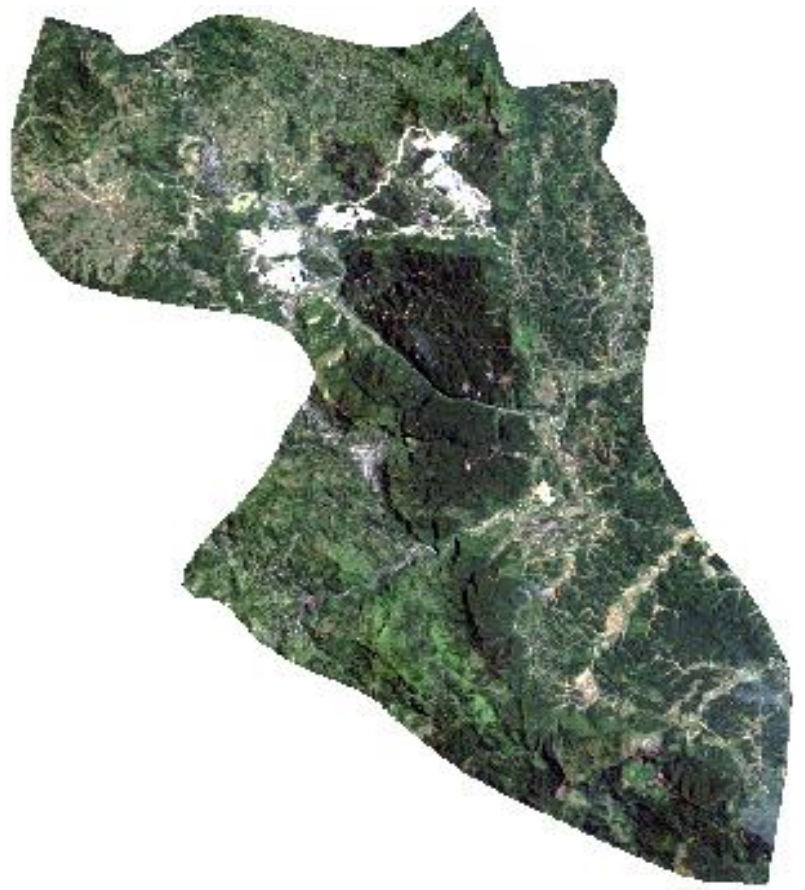

(b)

Gambar 4. Hasil True Color Komposit Band (a) Sebelum dan (b) Sesudah Koreksi Radiometrik (ToA)

\section{Klasifikasi Tutupan Lahan}

Klasifikasi tutupan lahan di Kota Sawahlunto dilakukan dengan menggunakan metode unsupervised classification. Metode tersebut menggunakan kombinasi band RGB (Red, Green, and Blue). Kombinasi band RGB ini diperoleh dari hasil komposit band 1 blue, band 2 green, dan band 3 red untuk Landsat 5 serta band 2 blue, band 3 green, dan band 4 red untuk landsat 8 . Hasil dari unsupervised classification mendapatkan 4 peta tutupan lahan sesuai tahun data Landsat yang sudah dikoreksi radiometrik. Klasifikasi ini terbagi menjadi 4 kelas yaitu: Hutan, Pemukiman, Danau atau Air, dan Tambang.

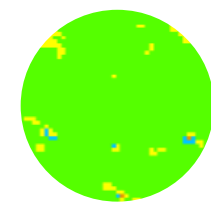

(a)

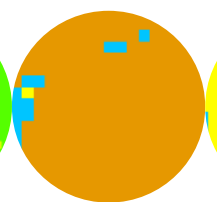

(b)

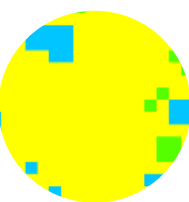

(c)

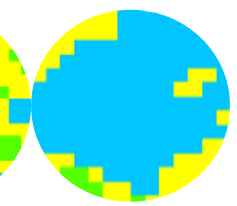

(d)
Gambar 5.Contoh kenampakan objek permukaan bumi hasil klasifikasi (a) Hutan, (b) Tambang, (c) Pemukiman, (d) Danau atau Air

Berdasarkan data hasil unsupervised classification, selanjutnya dihitung luasan wilayah setiap kelasnya. Perhitungan luasan tersebut didasarkan pada jumlah pixal setiap kelasnya dikalikan dengan luasan setiap pixel. Besarnya luasan setiap pixel dapat dilihat dari resulusi spasial citra yang digunakan. Karena resulusi spasial data yang digunakan adalah $30 \mathrm{~m}$ × $30 \mathrm{~m}$ maka luasan setiap pixel adalah $900 \mathrm{~m}^{2}$.

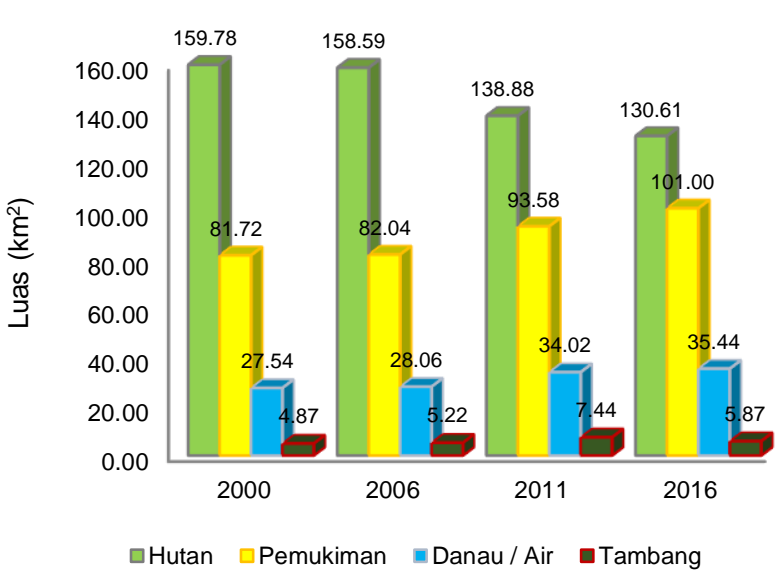

Gambar 6.Luas Tutupan Lahan Kota Sawahlunto Tahun $2000-2016$

Tabel 1 menunjukkan adanya pengurangan luas hutan di Kota Sawahlunto secara berkala. Perubahan luas hutan antara tahun 2000 sampai 2006 berkurang sebesar 159,78 $-158,59=1,19 \mathrm{~km}^{2}$. Pengurangan luasan hutan tersebut dikarenakan perubahan fungsi hutan yaitu hutan menjadi pemukiman sebesar $0,32 \mathrm{~km}^{2}$, hutan menjadi danau/air sebesar $0,52 \mathrm{~km}^{2}$, dan hutan menjadi tambang sebesar $0,35 \mathrm{~km}^{2}$. Perubahan luas hutan antara tahun 2006 sampai 2011 berkurang sebesar 158,59 - 138,88 $=19,72 \mathrm{~km}^{2}$. Pengurangan luasan hutan tersebut dikarenakan perubahan fungsi hutan yaitu hutan menjadi pemukiman sebesar $11,54 \mathrm{~km}^{2}$, hutan menjadi danau/air sebesar 5,95 $\mathrm{km}^{2}$, dan hutan menjadi tambang sebesar $2,22 \mathrm{~km}^{2}$. Periode tahun 2006 sampai 2011 perubahan hutan menjadi pemukiman mendominasi dua perubahan lainnya hal ini dikarenakan perluasan sektor tambang yang mengakibatkan bertambahnya penduduk serta dibangunnya banyak pemukiman menjadi salah satu penyebabnya (Andawarneri, 2006). 
Tabel 1. Perubahan Luasan Hutan

\begin{tabular}{lccc}
\hline \multirow{2}{*}{ Keterangan } & \multicolumn{3}{c}{ Luas $\left(\mathrm{km}^{2}\right)$ per periode Tahun } \\
\cline { 2 - 4 } & $2000-2006$ & $2006-2011$ & $2011-2016$ \\
\hline $\begin{array}{c}\text { Hutan menjadi } \\
\text { Pemukiman }\end{array}$ & 0,32 & 11,54 & 7,42 \\
$\begin{array}{c}\text { Hutan menjadi } \\
\text { Danau/Air }\end{array}$ & 0,52 & 5,95 & 1,43 \\
$\begin{array}{c}\text { Hutan menjadi } \\
\text { Tambang }\end{array}$ & 0,35 & 2,22 & $-1,58$ \\
\hline $\begin{array}{c}\text { Jumlah luasan } \\
\text { perubahan hutan }\end{array}$ & 1,19 & 19,72 & 7,27 \\
\hline
\end{tabular}

Perubahan luas hutan antara tahun 2011 sampai 2016 berkurang sebesar 138,88 - 130,61 = 7,27 $\mathrm{km}^{2}$. Pengurangan luasan hutan tersebut dikarenakan perubahan fungsi hutan yaitu hutan menjadi pemukiman sebesar 7,42 $\mathrm{km}^{2}$, hutan menjadi danau/air sebesar 1,43 $\mathrm{km}^{2}$, tetapi ada perubahan tambang menjadi hutan sebesar $1,58 \mathrm{~km}^{2}$. Nilai negatif menunjukkan perubahan hutan menjadi tambang pada periode 2011 sampai 2016 tidak terjadi, tetapi sebaliknya terjadi perubahan tambang menjadi hutan. Periode tahun 2011 sampai 2016 perubahan hutan menjadi pemukiman mendominasi dua perubahan lainnya hal ini dikarenakan sejak tahun 2012 banyak perusahaan tambang di Kota Sawahlunto yang tidak memperpanjang ijin perusahaannya (Sihombing, 2016). Selain hal tersebut, akibat peristiwa ledakan di area pertambangan yang menimbulkan banyak korban jiwa juga membuat Pemerintah Daerah Kota Sawahlunto menghentikan ijin beberapa perusahaan di daerah tersebut, serta akibat terhentinya aktivitas pertambangan di daerah yang ditutup, pemerintah daerah Kota Sawahlunto menyulap area pertambangan yang ditutup menjadi museum pendidikan. Jadi dalam kurun waktu tahun 2000 sampai 2016 perubahan luasan hutan secara besarbesaran terjadi pada periode tahun 2006 - 2016 sebesar $26,91 \mathrm{~km}^{2}$.

\section{Pengujian Akurasi}

Pengujian akurasi dilakukan untuk mendapatkan tingkat ketelitian hasil yang diperoleh dari metode unsupervised classification. Hasil pengujian akurasi ditampilkan dalam tabel matrik konfusi. Akurasi yang dihitung adalah User Accuracy, Producer Accuracy, dan Overall Accurary. Menurut Dotton (2017), Producer's accuracyberkaitan dengan omission error (inclusion). Producer's accuracy diperoleh dengan membagi pixel yang benar dalam suatu kelas dengan jumlah pixel pada kolom kelas tersebut. Sedangkan user's accuracy berkaitan dengan comission error (inclusion). User's accuracy diperoleh dengan membagi pixel yang benar dalam suatu kelas dengan jumlah pixel pada baris kelas tersebut. Selanjutnya Overall accurary menyajikan prosentase keakuratan hasil klasifikasi yang dihitung berdasarkan kesesuaian pikseldata di lapangan dengan hasil unsupervised classification. Menurut Sampurno dan Thoriq (2016), nilai akurasi di atas atau lebih dari $80 \%$ menunjukkan nilai akurasi yang tinggi.

Tabel 2. Matrik Konfusi Unsupervised Classification Tahun 2000

\begin{tabular}{|c|c|c|c|c|c|c|}
\hline \multirow{2}{*}{ Data Klasifikasi } & \multicolumn{5}{|c|}{ Data Ground Truth True Color Tahun 2000} & \multirow{2}{*}{$\begin{array}{c}\text { User Accuracy } \\
(\%)\end{array}$} \\
\hline & Hutan & Pemukiman & Danau / Air & Tambang & Row Total & \\
\hline Hutan & 10 & 0 & 0 & 0 & 10 & $100 \%$ \\
\hline Pemukiman & 0 & 10 & 0 & 0 & 10 & $100 \%$ \\
\hline Danau / Air & 0 & 0 & 10 & 0 & 10 & $100 \%$ \\
\hline Tambang & 0 & 0 & 0 & 10 & 10 & $100 \%$ \\
\hline Column Total & 10 & 10 & 10 & 10 & 40 & \\
\hline Producer Accuracy & $100 \%$ & $100 \%$ & $100 \%$ & $100 \%$ & & \\
\hline Overall accurary & \multicolumn{6}{|c|}{$100 \%$} \\
\hline
\end{tabular}

Dalam Tabel 2 dapat dilihat data yang diklasifikasikan sebagai kelas hutan sebesar 10 dari total sampel dengan tidak adanya omission error atau tidak ada kesalahan klasifikasi pada kelas hutan. Pada kolom kelas hutan yang diklasifikasikan sebagai hutan sebesar 10 dan tidak ada tambahan klasifikasi dari kelas lainnya (nocommision eror). Kelas pemukiman sebesar 10 dari total sample dengan tidak adanya omission eror atau tidak ada kesalahan klasifikasi pada kelas pemukiman. Pada kolom kelas pemukiman yang diklasifikasikan sebagai hutan sebesar 10 dan tidak ada tambahan klasifikasi dari kelas lainnya (commision eror). Kelas danau/air sebesar 10 dari total sample dengan tidak adanya omission eror atau tidak ada kesalahan klasifikasi pada kelas pemukiman. Pada kolom kelas tambang yang diklasifikasikan sebagai hutan sebesar 10 dan tidak ada tambahan klasifikasi (commision eror)dari kelas lainnya. Dari data tersebut nilai producer accurary dan user's accurary sebesar $100 \%$ setiap kelasnya. Sehingga nilai Overall accurary klasifikasi sebesar 100\%.

Berdasarkan matrik konfusi tersebut dapat disimpulkan nilai Overall accuracy tertinggi terdapat pada tahun 2000 sebesar $100 \%$ dan terendah pada tahun 2016 sebesar $92,5 \%$. Hal ini terjadi dikarenakan tingkat cloud cover yang digunakan pada setiap tahunnya. Cloud cover pada tahun 2000 sebesar 9,0\% dan cloud cover pada tahun 2016 sebesar $14,3 \%$. Jadi semakin tinggi cloud cover data yang digunakan maka akan semakin rendah overall accurary yang didapat dan semakin rendah cloud coverdata yang digunakan maka akan semakin tinggi overall accurary yang didapat.

Nilai NDVI pemukiman yang didapatkan untuk tahun 2000 sampai 2011 menunjukan penurunan secara berkala yang dilihat dari nilai tengah NDVI yang didapatkan. Namun, nilai tengah NDVI pada tahun 2016 menunjukkan peningkatan sebesar 0,65 . Nilai NDVI tambang yang didapatkan untuk tahun 2000 sampai 2006 menunjukan penurunan secara berkala yang dilihat dari nilai tengah NDVI yang didapatkan. Namun, nilai tengah NDVI pada tahun 2011 sampai 2016 menunjukkan peningkatan. Nilai NDVI danau/air yang didapatkan untuk tahun 2000 sampai 2006 menunjukan peningkatan secara berkala yang dilihat dari nilai tengah NDVI yang didapatkan. Namun, nilai tengah NDVI pada tahun 2011 sampai 2016 menunjukkan penurunan sebesar 0,08 (Gambar 7). 


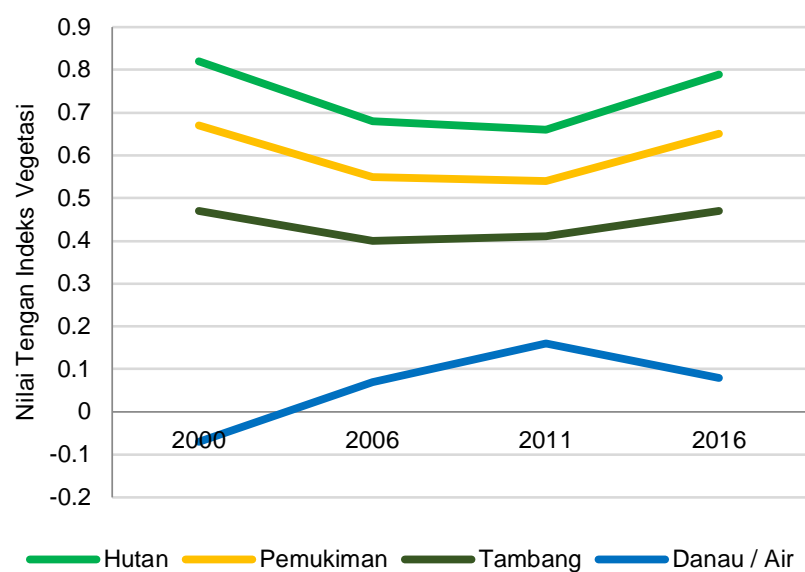

Gambar 7. Grafik Nilai NDVI Sawahlunto Tahun 20002016

\section{Nilai VIDN Kota Sawahlunto}

Dalam kurun waktu tahun 2000 - 2011 nilai VIDN dari hutan menurun dikarenakan adanya perubahan hutan menjadi pemukiman, danau/air, dan tambang. Pada tahun 2011 - 2016 nilai VIDN hutan menjadi meningkat, hal ini bisa disebabkan karena berkurangnya daerah pertambangan dan kembalinya fungsi hutan di Kota Sawahlunto. Jadi, aktifitas pembukaan lahan hutan menjadi tambang, pemukiman, dan danau/air pada periode tahun 2000 - 2011 mengurangi kualitas dari kehijauan hutan. Tetapi berkurangnya aktifitas pembukaan lahan menjadi pemukiman, tambang, dan danau/air menambah kualitas dari hutan yang dapat terlihat dari Tabel 3.

Tabel 3. Nilai VIDN Hutan Tahun 2000 - 2016

\begin{tabular}{cc}
\hline Periode Tahun & Nilai VIDN \\
\hline $2000-2006$ & $-0,14$ \\
$2006-2011$ & $-0,02$ \\
$2011-2016$ & 0,13 \\
\hline
\end{tabular}

Peta hasil klasifikasi tutupan lahan kota Sawahlunto untuk tahun 2006 dan 2016 ditunjukkan pada Gambar 8. Dari peta tersebut dapat diamati dengan jelas adanya perubahan tutupan lahan di Sawahlunto terutama pada jenis tutupan lahan pemukiman dan tambang.

Sementara peta nilai NDVI untuk wilayah penelitian yang sama di kota Sawahlunto ditunjukkan pada Gambar 9 dan terlihat bahwa ada beberapa lokasi yang sebelumnya berwarna hijau (nilai NDVI tinggi) berubah menjadi warna merah (mengalami penurunan nilai NDVI).
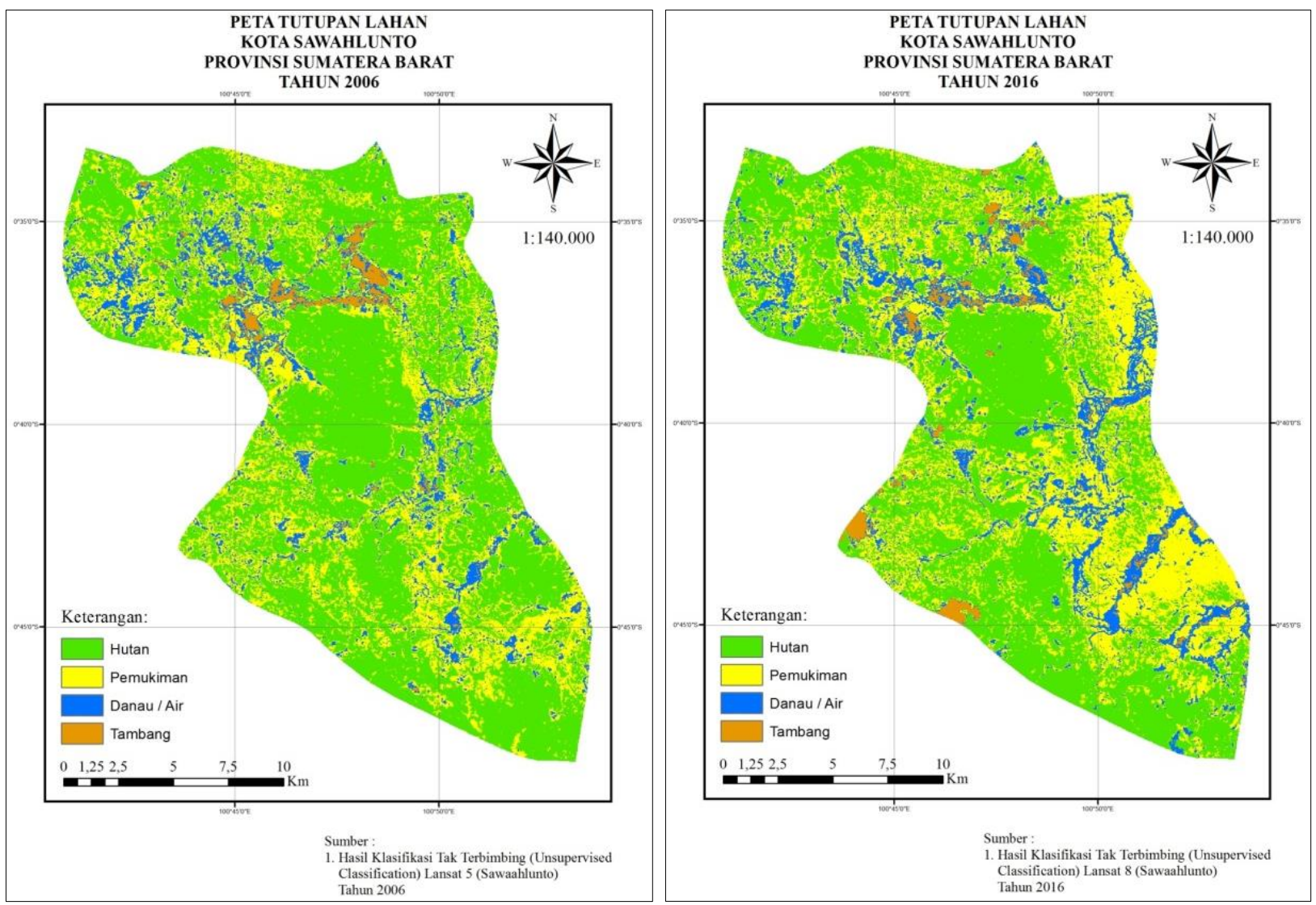

Gambar 8. Peta tutupan lahan Kota Sawahlunto Tahun 2006 dan 2016

\section{KESIMPULAN}

Kesimpulan yang dapat diambil dari penelitian ini adalah hasil aplikasi metode klasifikasi tak terbimbing (unsupervised classification) terhadap tutupan lahan dengan citra Landsat di Kota Sawahlunto dari tahun 2000 sampai 2016 memperlihatkan perubahan luas area kelas hutan (29,17 ha), pemukiman (19,28 ha), tambang (1 ha), dan danau atau air (7,9 ha). Perubahan tersebut dapat juga dilihat secara visual melalui peta tutupan lahan. Nilai indeks vegetasi pada citra satelit Landsat di Kota Sawahlunto dari tahun 2000 sampai 2016 menjukkan hasil yang dapat dilihat dalam bentuk Peta NDVI dan Peta VIDN. Nilai NDVI yang menurun dari 0,82 menjadi 0,78 dapat menunjukkan adanya perubahan atau menurunnya tingkat kehijauan vegetasi yang terdapat di Kota Sawalunto. 

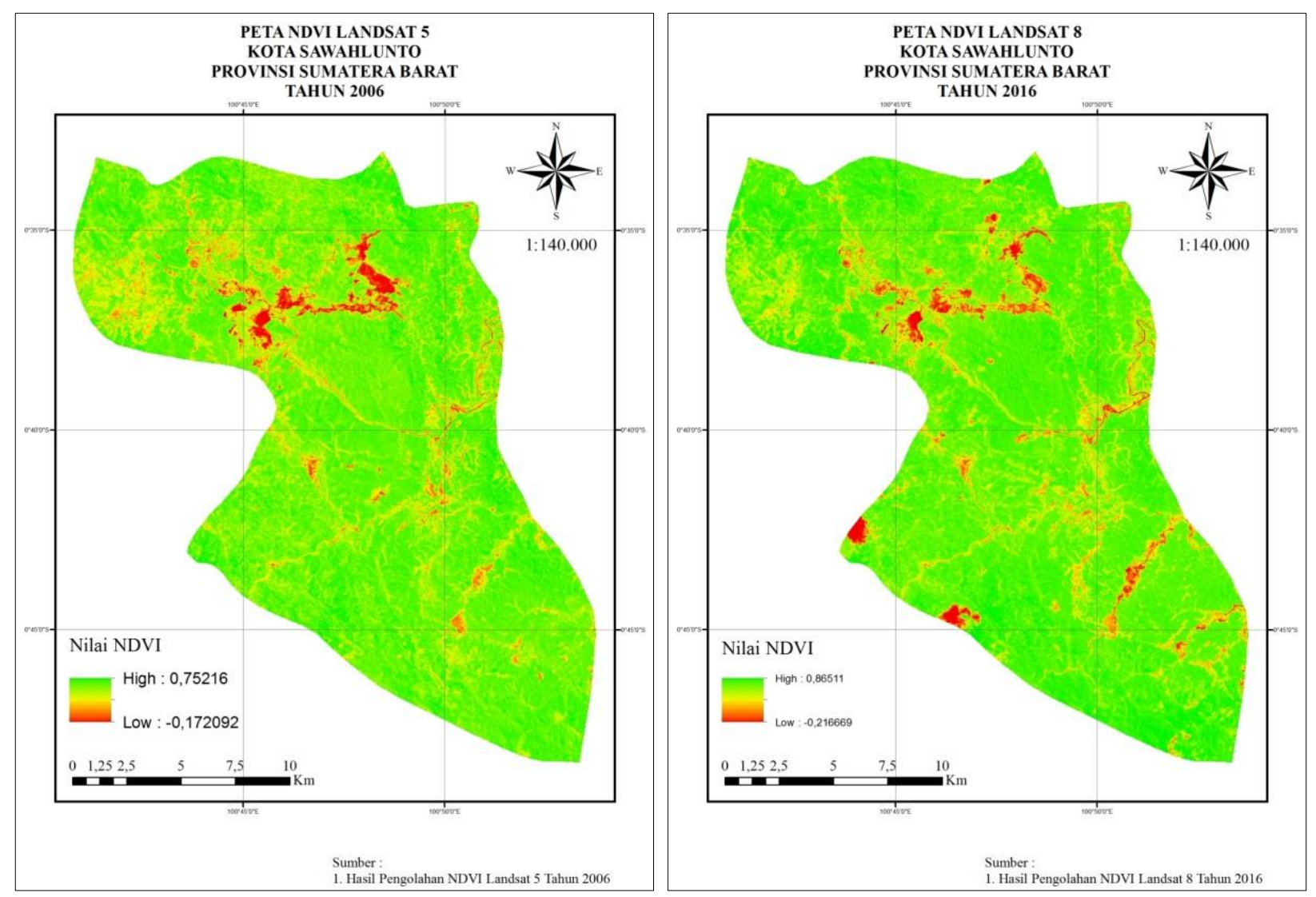

Gambar 9. Peta NDVI Kota Sawahlunto Tahun 2006 dan 2016

\section{DAFTAR PUSTAKA}

Alba, J. M. F., V. F. Schroder, dan M. R. R. Nóbrega. (2012). Land Cover Change Detection in Southern Brazil Through Orbital Imagery Classification Methods. Dalam Remote Sensing - Applications. Editor D. B. Escalante: Rijeka-Croatia. InTech.

Amliana, D. R., Y. Prasetyo, dan A. Sukmono. (2016). Analisis Perbandingan Nilai NDVI Landsat 7 dan Landsat 8 pada Kelas Tutupan Lahan (Studi Kasus : Kota Semarang, Jawa tengah). Jurnal Geodesi Undip 5: 264.

Andawarneri. (2006). Status Lingkungan Hidup Daerah (SLHD) Provinsi Sumatera Barat Tahun 2006. Padang.

Arnanto, A. (2013). Pemanfaatan Transformasi Normalized Difference Vegetation Index (NDVI) Citra Landsat TM untuk Zonasi Vegetasi di Lereng Merapi Bagian Selatan. Geomedia 11: 155.

Cahyono, B. E., A. T. Nugroho, dan J. Husen. (2018). Karakteristik Time Series Reflektansi Tanaman Padi Varietas Ciherang dengan Analisis RGB Citra Fotografi. Jurnal Fisika FLUX 15 (1): 59-65.

Campbell, J. B. (2002). Introduction to Remote Sensing. 3 rd Ed. New York: The Guildford Press:

Compton, J., Tucker, J. R. G., Townshend, dan T. E. Goff. (1985). African Land-Cover Classification Using Satellite Data. Science 227 (4685).

Dotton, J. A. (2017). Classification Accurarcy Assessment Pennsylvania, Departement of Geography, PennState Collage of Earth and Mineral Sciences. https://www.eeducation.psu.edu/geog883/node/524. [Diakses pada: 3 Januari].
Frahma, Y. F., B. E. Cahyono, dan A. T. Nugroho. (2018). Analisis Tingkat Kehijauan Hutan Daerah Pertambangan Sawahlunto Dengan Metode NDVI Berdasarkan Citra Landsat Tahun 2006-2016. Jurnal SPEKTRA 3 (1): 37-45.

Levin, N. (1999). Fundamentals of Remote Sensing. Trieste, Italy: International Maritime Academy:

llandayani, D., dan A. Setiyadi. (2003). Remote Sensing (Penginderaan Jauh). Jurnal Edisi Mei 20038.

Rees, W. G. (2001). Physical Principles of Remote Sensing. $2^{\text {nd }} \mathrm{Ed}$. Cambridge: Cambridge University Press:

Sabins, F. F. (1987). Remote Sensing: Principles and Interpretation. $2^{\text {nd }}$ Ed. New York: W.H. Freeman and Company

Sampurno, R. M., dan A. Thoriq. (2016). Klasifikasi Tutupan Lahan Menggunakan Citra Landsat 8 Operational Land Imager (OLI) Di Kabupaten Sumedang. Jurnal Teknotan 10: 61.

Sihombing, A. (2016). Menapaki Jejak Tambang SawahLunto Sumatera Barat, Cumilebay. http://www.cumilebay.com/2016/08/menapaki-jejaktambang-sawahlunto.html. [Diakses pada: 24 November].

Sutanto. (1994). Penginderaan Jauh Jilid 1. Yogyakarta: Gajah Mada University Press:

Unesco. (2017). Sawahlunto Old Coal Mining Town. In United Nations Educational, Scientific and Cultural Organization.

Wahyuni, S. (2015). Identifikasi Karakteristik dan Pemetaan Tutupan Lahan Menggunakan Citra Landsat 8 (OLI) di Kabupaten Ogan Komering Ilir Provinsi Sumatera Selatan, Bogor, Fakultas Kehutanan, Institut Pertanian Bogor. 